\title{
TWO SAINFOIN (ONOBRYCHIS VICIIFOLIA SCOP.) CULTIVARS DIFFER IN THEIR RESPONSES TO NEUTRAL AND SALINE- ALKALI STRESS DURING SEED GERMINATION AND EARLY SEEDLING GROWTH
}

\author{
LI, S. J. ${ }^{1}-$ ZHU, Y. H. ${ }^{1}-$ WHITE, J. F. ${ }^{2}-$ WeI, M. ${ }^{1}-$ WU, G. Q. ${ }^{1 *}$ \\ ${ }^{1}$ School of Life Science and Engineering, Lanzhou University of Technology, \\ Lanzhou 730050, China \\ (phone: +86-931-297-6650; fax: +86-931-297-3367) \\ ${ }^{2}$ Department of Plant Biology, Rutgers University, New Brunswick, NJ 08901, USA \\ *Corresponding author \\ e-mail: gqwu@lut.edu.cn; phone: +86-931-297-6060 \\ (Received $27^{\text {th }}$ Jun 2021; accepted $20^{\text {th }}$ Sep 2021)
}

\begin{abstract}
Salinity is one of the major environmental factors limiting plant growth and development. Two cultivars (the native "Gansu," GS; and the imported "Italian," IT) of sainfoin (Onobrychis viciifolia Scop.) were exposed to two neutral salts $\left(\mathrm{NaCl}\right.$ and $\left.\mathrm{Na}_{2} \mathrm{SO}_{4}\right)$ and two alkaline salts $\left(\mathrm{Na}_{2} \mathrm{CO}_{3}\right.$ and $\mathrm{NaHCO}_{3}$ ) at concentrations ranging from 0-300 mM. After seven days seed germination rates and radicle and hypocotyl lengths were compared. Exposure only to $50 \mathrm{mM}$ neutral salts did not affect significantly relative germination rates compared to control $(0 \mathrm{mM})$. In contrast, higher concentrations of neutral salts and alkaline salts significantly inhibited germination rates and reduced radicle and hypocotyl lengths. Although the two cultivars were visually similar in appearance and had similar patterns in response to saline and alkaline stresses, GS had relatively higher threshold germination concentration compared to IT, and the radicles and hypocotyls of seedlings grown under $\mathrm{NaCl}$ and $\mathrm{Na}_{2} \mathrm{SO}_{4}$ were longer than for IT, indicating that GS is more salt-tolerant. Under neutral salt stress, the recovery germination percentage increased with higher salt concentration. However, under alkaline salt stress, the recovery germination percentage sharply decreased with increasing salt concentration. These results suggest that the damage caused by alkaline salts is more severe than those caused by neutral salts. The present study provides novel insights into the responses of seed germination to different types of salinity in an important forage species.
\end{abstract}

Keywords: forage, germination rate, hypocotyl, radical, physiological response

\section{Introduction}

Abiotic stress seriously affects plant growth and development, resulting in crop failure and reducing average crop yields worldwide (Muscolo et al., 2014; Khalil et al., 2016; Partheeban et al., 2017; Niu et al., 2018). Salinity is one of the most important abiotic factors and impacts almost every aspect of plant biochemistry and physiology, from seed germination and seedling growth to the final production and yield from mature crops (Lu et al., 2010; Gebremedhn and Berhanu, 2013; Radic et al., 2019). Exposure of seeds to saline conditions may compromise subsequent seedling establishment (Albuquerque and Carvalho, 2003; Ahmadvand et al., 2012). Indeed, salinization has already affected over 800 million hectares of land, approximately $6 \%$ of the total land area worldwide (Munns and Tester, 2008; Wu et al., 2015a).

Assessing salt tolerance of seed germination is extremely important because successful establishment depends entirely on seed germination, and seeds with more 
rapid germination under saline conditions are expected to establish faster and accumulate more biomass (Gorai and Neffati, 2007; Petrovic et al., 2016). One of the most common experiments to study seed germination sensitivity to salinity involves the application of $\mathrm{NaCl}, \mathrm{Na}_{2} \mathrm{SO}_{4}, \mathrm{Na}_{2} \mathrm{CO}_{3}$, and $\mathrm{NaHCO}_{3}$ to seed and seedling media (Zahra et al., 2011; Idris and Ali, 2015; Hu et al., 2018; Li and Zhao, 2018).

Sainfoin (Onobrychis viciifolia Scop.) is one of the most bloat-safe forage legume crops with high tannin levels, and it is renowned for its medicinal value to grazing animals (Mohajer et al., 2014). Recently, various studies have characterized the environmental preferences, agronomy, plant-microbial interactions, and crop protection of sainfoin (Okcu and Topaloglu, 2019). Sainfoin is an important forage species in agriculture preferred by farmers over other forage legumes. It is widely distributed throughout the arid and semi-arid areas of northern China, Europe, and Russia (Baldinger et al., 2014; Wu et al., 2017; Cirujeda et al., 2019). Since meat products have become more popular as people's living standards have improved, increasing forage crops will be crucial in increasing livestock production. However, in some areas, development of forage crops is negatively affected by abiotic stress. As a result, forage plants may become the focus of breeding programs, particularly for developing salttolerant varieties. For sainfoin cultivation, the most important problem is poor germination (Okcu and Topaloglu, 2019), which always results in undesirable establishment and, occasionally, in crop failure (Abbasdokht et al., 2014; Radic et al., 2019). Our previous studies showd that low salt $(5-50 \mathrm{mM} \mathrm{NaCl})$ did not affect plant growth of sainfoin, whereas high salt $(100$ and $200 \mathrm{mM})$ significantly limited its growth (Wu et al., 2017). Recently, it was reported that the damages caused by alkaline $\left(\mathrm{Na}_{2} \mathrm{CO}_{3}\right)$ stress on the growth of sainfoin plants were more serious than those caused by saline-alkaline ( $\left.\mathrm{NaCl}: \mathrm{Na}_{2} \mathrm{CO}_{3}\right)$ stress (Wu et al., 2021). However, the studies on effects of neutral and alkaline salts on seed germination and early seedling growth of sainfoin have been rarely performed.

The objective of this work was to investigate and compare the effects of two common salt stress factors, neutral salinity $\left(\mathrm{NaCl}\right.$ and $\left.\mathrm{Na}_{2} \mathrm{SO}_{4}\right)$ and alkaline salinity $\left(\mathrm{Na}_{2} \mathrm{CO}_{3}\right.$ and $\mathrm{NaHCO}_{3}$ ), on seed germination and seedling growth of two sainfoin cultivars. The results of the present study would not only provide novel insights into the responses of seed germination to different types of salinity in forage species, but also provide a practical basis for improvement and utilization of saline soil.

\section{Materials and methods}

\section{Plant materials}

This study was carried out in the Lab of Plant Physiology and Ecology at Lanzhou University of Technology, Lanzhou, Gansu Province, China, from March through December, 2019. The seeds of sainfoin (O. viciifolia Scop.) cultivars "Gansu" (GS, native breed) and "Italian" (IT, imported breed) were purchased from Lanzhou Nongfeng Seed and Seedling Technology Co., Ltd. and Gansu Mammoth Agriculture Co., Ltd., respectively. The seeds of these two cultivars are very similar and cannot be distinguished based on appearance. The masses of 1000 seeds of GS and IT were 23.03 and $21.07 \mathrm{~g}$, respectively. Prior to the experiment, excessively large or small seeds were discarded, and seeds of uniform size were collected for the germination experiments. Seeds were kept in a cold chamber at $4{ }^{\circ} \mathrm{C}$ until the start of the experiments. 


\section{Germination test}

A total of four salinity types $\left(\mathrm{NaCl}, \mathrm{Na}_{2} \mathrm{SO}_{4}, \mathrm{Na}_{2} \mathrm{CO}_{3}\right.$, and $\left.\mathrm{NaHCO}_{3}\right)$ were applied. Seeds of GS and IT were exposed to two neutral salinities $\left(\mathrm{NaCl}\right.$ and $\left.\mathrm{Na}_{2} \mathrm{SO}_{4}\right)$ and two alkaline salinities $\left(\mathrm{Na}_{2} \mathrm{CO}_{3}\right.$ and $\left.\mathrm{NaHCO}_{3}\right)$ at $0,50,100,200,250$, and $300 \mathrm{mM}$ during a seven-day period and their germination assessed.

Seeds were first surface sterilized in a 3\% sodium hypochlorite solution for $8 \mathrm{~min}$, then rinsed with the sterile distilled water five times, soaked in the distilled water for $12 \mathrm{~h}$, and briefly dried on filter paper. Fifty seeds were randomly placed on 9-cm diameter Petri dishes with three layers of filter paper wetted with $12 \mathrm{~mL}$ of the treatment solutions. The filter paper and solutions were changed each day. Petri dishes were randomly placed in the dark in a precision incubator that maintained the temperature at $18{ }^{\circ} \mathrm{C}$. Three independent replicates were conducted for each treatment.

After $7 \mathrm{~d}$ of salt exposure, ungerminated seeds were transferred to Petri dishes with only distilled water and incubated at $18{ }^{\circ} \mathrm{C}$ for an additional $6 \mathrm{~d}$.

\section{Data collection}

Seeds were considered to have germinated when their radicle length was at least $1 \mathrm{~mm}$. The number of seeds germinated on each Petri dish was recorded daily during the sevenday salinity exposure. The hypocotyl and radicle lengths were measured using a ruler on the seventh day. The germination rate (GR) was calculated according to Hu et al. (2018) as

$$
G R(\%)=\frac{\mathrm{a}}{b} \times 100
$$

where $a$ is the number of germinated seeds and $b$ is the number of total seeds per treatment. The recovery germination percentage (RGP) was calculated as

$$
R G P(\%)=\frac{c}{d} \times 100
$$

where $c$ is the number of newly germinated seeds in recovery test, and $d$ is the number of seeds transferred to the distilled water treatment (Zhang et al., 2014).

\section{Statistical analysis}

Data analysis was performed using SPSS 22.0 (Chicago, USA). Two-way and threeway ANOVAs using salinity type, salinity concentration, and cultivar, as the factors were performed to analyze the differences among the four salinity types, the seven salinity concentrations, the two cultivars, and their interactions. Duncan's Multiple Range tests were used to determine significant differences between means at the $P<0.05$ level.

\section{Results}

\section{Effects of neutral and alkaline salts on seed germination rate}

We compared the effects of different concentrations of neutral salinities $(\mathrm{NaCl}$ and $\left.\mathrm{Na}_{2} \mathrm{SO}_{4}\right)$ and alkaline salinities $\left(\mathrm{NaHCO}_{3}\right.$ and $\left.\mathrm{Na}_{2} \mathrm{CO}_{3}\right)$ on the time courses of seed germination (Figs. 1 and 2). 

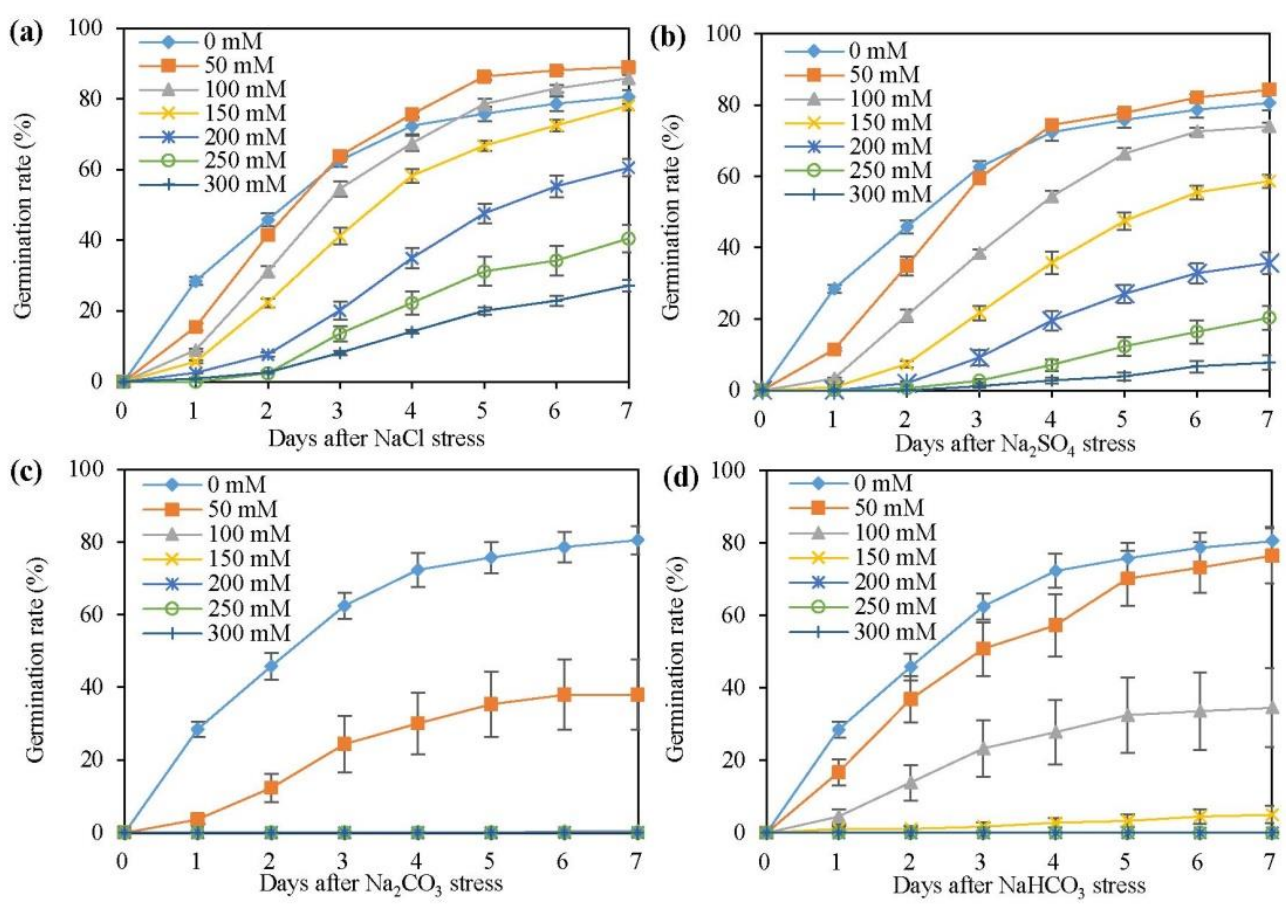

Figure 1. Time course of seed germination of the sainfoin cultivar "Gansu" (GS) subjected to $\mathrm{NaCl}(a), \mathrm{Na}_{2} \mathrm{SO}_{4}(b), \mathrm{Na}_{2} \mathrm{CO}_{3}(c)$, and $\mathrm{NaHCO}_{3}(d)$ in various concentrations (0, 50, 100, 150, 200, 250, and $300 \mathrm{mM}$ ) during a seven-day period. Fifty seeds were pooled in each replicate $(n=3)$. Values are mean \pm standard error $(S E)$, and error bars represent $S E$
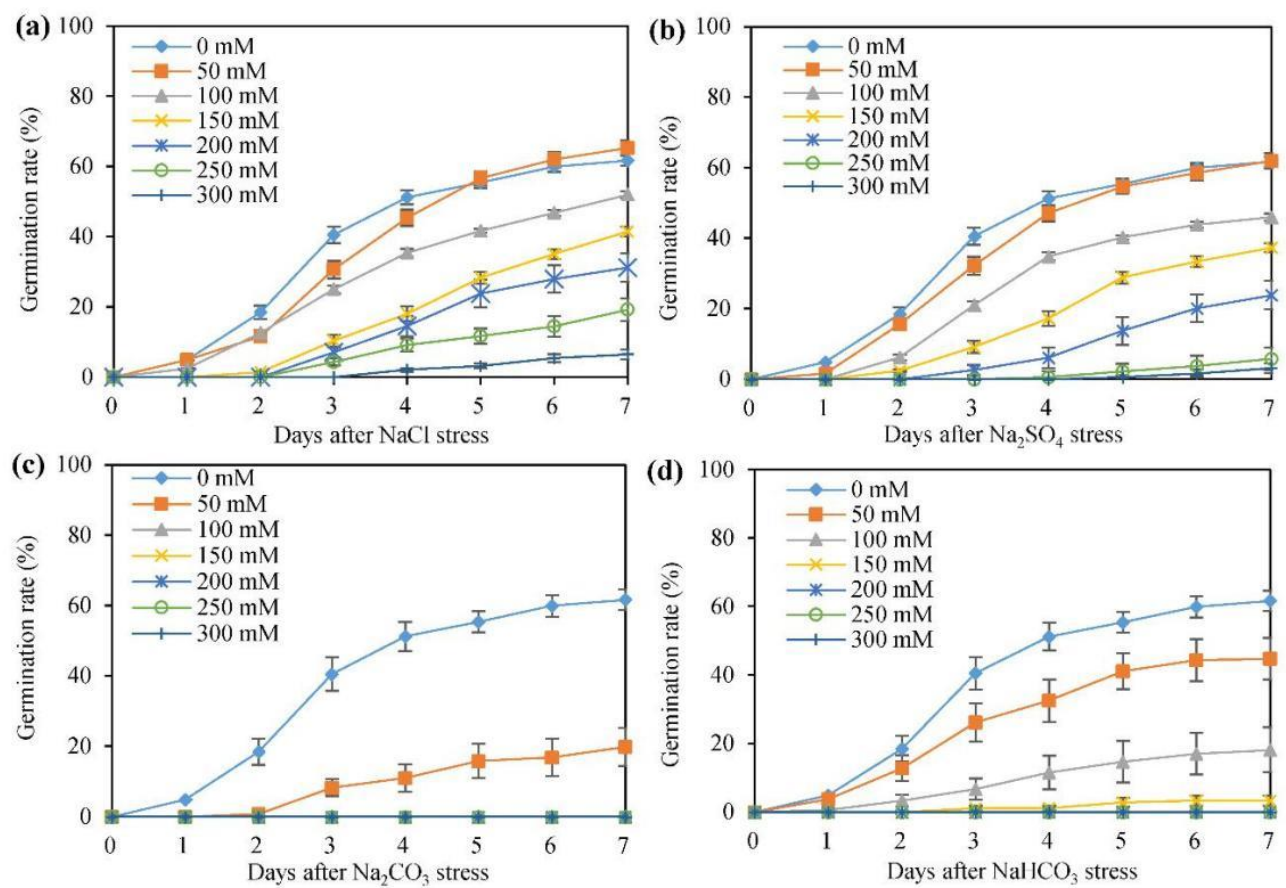

Figure 2. Time course of seed germination of the sainfoin cultivar "Italian" (IT) subjected to $\mathrm{NaCl}(a), \mathrm{Na}_{2} \mathrm{SO}_{4}(b), \mathrm{Na}_{2} \mathrm{CO}_{3}(c)$, and $\mathrm{NaHCO}_{3}(d)$ in various concentrations (0, 50, 100, 150, 200, 250, and $300 \mathrm{mM}$ ) during a seven-day period. Fifty seeds were pooled in each replicate $(n=3)$. Values are mean \pm standard error $(S E)$, and error bars represent $S E$ 
GS had a higher rate of seed germination than IT under both normal (no added salts) and saline treatments. At the end of the experiment on the seventh day, the highest germination rate under $\mathrm{NaCl}$ exposure for both cultivars occurred with the $50 \mathrm{mM} \mathrm{NaCl}$ treatment, followed by $100 \mathrm{mM}$ in GS and $0 \mathrm{mM}$ in IT. Germination rates were significantly reduced by higher salt concentrations in both GS $(200,250$, and $300 \mathrm{mM})$ and IT $(100,150,200,250$, and $300 \mathrm{mM})$ compared to control $(0 \mathrm{mM})$ (Figs. 1a and $2 a$ ). Under $\mathrm{Na}_{2} \mathrm{SO}_{4}$ treatments, the concentration of $50 \mathrm{mM}$ did not affect germination rate in either GS or IT, while higher concentrations (100-300 mM) significantly decreased germination rate in both cultivars compared to the control $(0 \mathrm{mM})$ (Figs. $1 \mathrm{~b}$ and $2 b$ ). Under $50 \mathrm{mM} \mathrm{Na} 2 \mathrm{CO}_{3}$ treatment, GS began to germinate on the first day, while IT did not begin to germinate until the third day. By the seventh day, the $50 \mathrm{mM}$ concentration of $\mathrm{Na}_{2} \mathrm{CO}_{3}$ significantly reduced gemination rates of GS and IT by $52.9 \%$ and $67.9 \%$, respectively, compared to the $0 \mathrm{mM}$ control concentration, whereas high concentrations (100-300 $\mathrm{mM}$ ) completely inhibited germination in both cultivars (Figs. $1 c$ and 2c). Under $\mathrm{NaHCO}_{3}$ treatment, germination rates were reduced significantly both in GS and IT by $50 \mathrm{mM}$ concentration over a seven-day period compared to the $0 \mathrm{mM}$ control. Exposure to $100 \mathrm{mM} \mathrm{NaHCO}_{3}$ observably decreased germination rates in GS and IT to levels significantly lower than at a concentration of $50 \mathrm{mM}$. Both cultivars maintained lower germination rates when exposed to $150 \mathrm{mM}$ $\mathrm{NaHCO}_{3}$, and germination was almost completely inhibited under high concentrations $\left(200,250\right.$, and $300 \mathrm{mM}$ ) of $\mathrm{NaHCO}_{3}$ throughout the seven days of treatment (Figs. Id and $2 d)$.

The effects of salt exposure on relative gemination rate in the two cultivars were further analyzed. Under neutral salts $\left(\mathrm{NaCl}\right.$ and $\left.\mathrm{Na}_{2} \mathrm{SO}_{4}\right)$, the relative germination rates both in GS and IT remained unchanged at $50 \mathrm{mM}$, but relative germination rate decreased significantly with increasing salt concentration from 100 to $300 \mathrm{mM}$ (Fig. 3a, b).

Interestingly, the relative germination rate of GS was higher than IT under both $\mathrm{NaCl}$ and $\mathrm{Na}_{2} \mathrm{SO}_{4}$ treatments. Furthermore, $\mathrm{Na}_{2} \mathrm{SO}_{4}$ had a stronger inhibitory effect on seed gemination than $\mathrm{NaCl}$, especially at high concentrations. Under alkaline salts $\left(\mathrm{Na}_{2} \mathrm{CO}_{3}\right.$ and $\mathrm{NaHCO}_{3}$ ), the increasing of salt concentration reduced significantly the relative germination rates, reaching zero at $100 \mathrm{mM} \mathrm{Na}_{2} \mathrm{CO}_{3}$ and $200 \mathrm{mM} \mathrm{NaHCO}_{3}$ (Fig. 3c, d), indicating that $\mathrm{Na}_{2} \mathrm{CO}_{3}$ more strongly inhibited seed germination than $\mathrm{NaHCO}_{3}$. The relative germination rate of GS was significantly higher than that of IT when exposed to 50 and $100 \mathrm{mM} \mathrm{NaHCO}$ (Fig. 3d). Moreover, the results of the two-way ANOVA showed that the effects of salinity type, salinity concentration, and their interaction on germination rates were significant in GS. However, in IT, both salt type and salt concentration had significant effects on germination of IT, but the interaction between salt type and salt concentration was not significant (Table 1).

Table 1. Two-way ANOVA of effects of salinity type and salinity concentration on germination rate and lengths of the hypocotyl and radicle in two sainfoin cultivars, "Gansu" (GS) and "Italian" (IT), exposed to salinity stress

\begin{tabular}{c|c|c|c|c|c|c}
\hline \multirow{2}{*}{ Variable and source of variation } & \multicolumn{3}{|c|}{ GS } & \multicolumn{3}{c}{ IT } \\
\cline { 2 - 6 } & $\begin{array}{c}\text { Germination } \\
\text { rate }\end{array}$ & $\begin{array}{c}\text { Hypocotyl } \\
\text { length }\end{array}$ & $\begin{array}{c}\text { Radicle } \\
\text { length }\end{array}$ & $\begin{array}{c}\text { Germination } \\
\text { rate }\end{array}$ & $\begin{array}{c}\text { Hypocotyl } \\
\text { length }\end{array}$ & $\begin{array}{c}\text { Radicle } \\
\text { length }\end{array}$ \\
\hline Salinity type $(\mathrm{df}=3)$ & $24.685^{* *}$ & $14.698^{* *}$ & $27.350^{* *}$ & $7.886^{* *}$ & $29.865^{* *}$ & 1.036 \\
Salinity concentration $(\mathrm{df}=6)$ & $62.195^{* *}$ & $54.182^{* *}$ & $123.842^{* *}$ & $62.236^{* *}$ & $63.289^{* *}$ & $23.219^{* *}$ \\
Salinity type $\times$ concentration $(\mathrm{df}=18)$ & $3.130^{* *}$ & $6.363^{* *}$ & $3.310^{* *}$ & 1.536 & $4.466^{* *}$ & 1.345 \\
\hline
\end{tabular}

$* P<0.05 ; * * P<0.01$ 

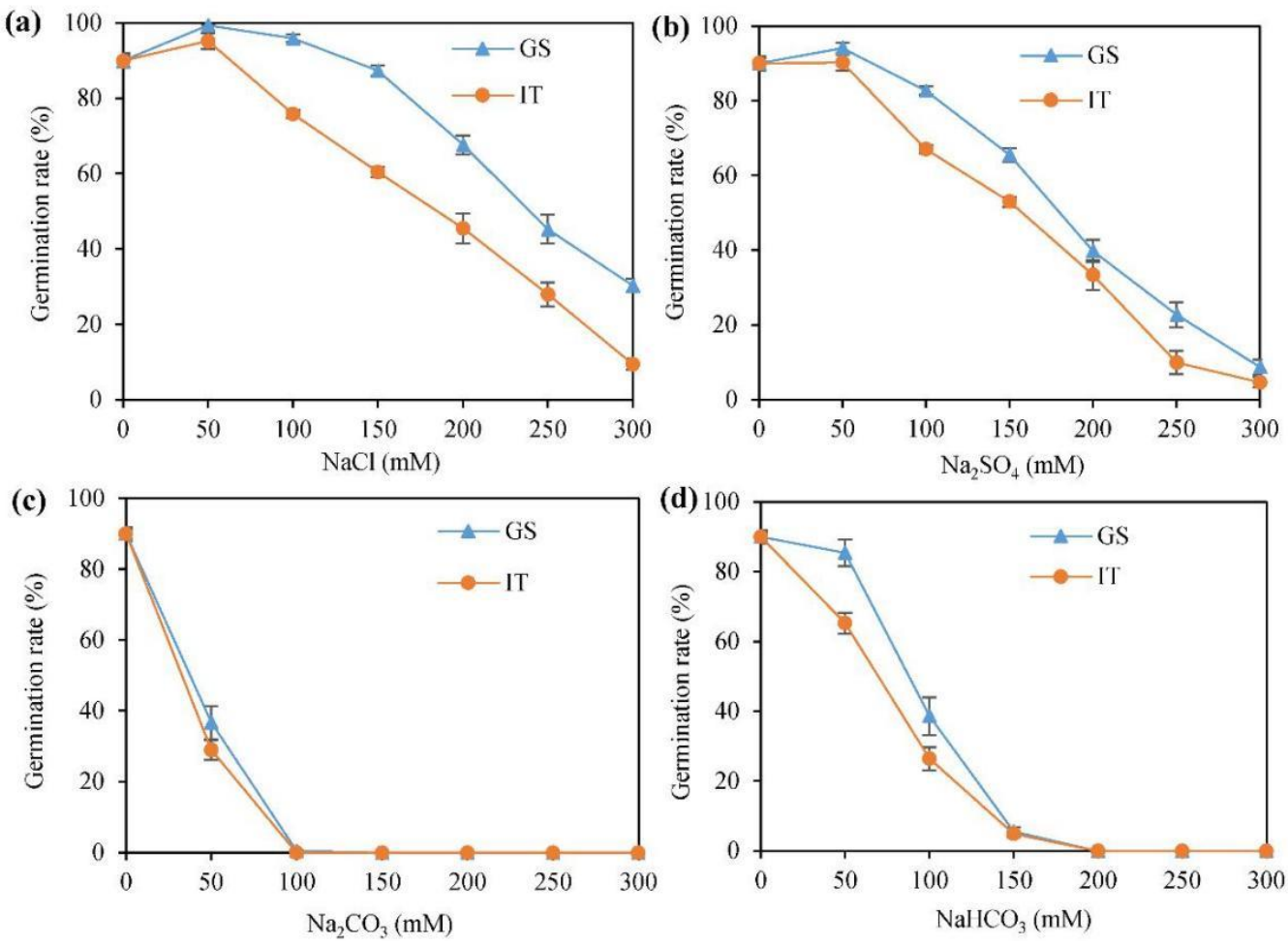

Figure 3. Germination rates of seeds in two sainfoin cultivars "Gansu” (GS) and "Italian" (IT) after subjected with $\mathrm{NaCl}(a), \mathrm{Na}_{2} \mathrm{SO}_{4}(b), \mathrm{Na}_{2} \mathrm{CO}_{3}(c)$, and $\mathrm{NaHCO}_{3}(d)$ of various concentrations $(0,50,100,150,200,250$, and $300 \mathrm{mM})$ for $7 \mathrm{~d}$. Fifty seeds were pooled in each repeat $(n=3)$. Values are mean \pm standard error $(S E)$ and error bars represent $S E$

\section{Effect of neutral and alkaline salts on growth of hypocotyl and radicle in two sainfoin cultivars during seed germination}

To explore effects of different kinds of salts on seedling growth after seed germination, the lengths of hypocotyl and radicle were measured at the end of the 7-day salt exposure. As shown in Table 2, under neutral salts, all concentrations (50-300 mM) significantly reduced the lengths of hypocotyl and radicle in both GS and IT compared to the control $(0 \mathrm{mM})$.

At the same salt concentration, the reduction of hypocotyl and radicle lengths by $\mathrm{NaCl}$ was less than by $\mathrm{Na}_{2} \mathrm{SO}_{4}$ in both cultivars. For example, at $300 \mathrm{mM} \mathrm{NaCl}$ and $\mathrm{Na}_{2} \mathrm{SO}_{4}$, hypocotyl length in GS was reduced by $89.9 \%$ and $94.9 \%$, respectively, compared to control $(0 \mathrm{mM})$. Under $\mathrm{Na}_{2} \mathrm{CO}_{3}$ stress, the minimum concentration needed to completely inhibit growth of both the hypocotyl and the radicle was 150 $\mathrm{mM}$ in GS, but only $100 \mathrm{mM}$ in IT. However, under $\mathrm{NaHCO}_{3}$ stress, the minimum concentration to completely inhibit growth was $200 \mathrm{mM}$ in both cultivars (Table 2). The results of a two-way ANOVA showed that the effects of salt type, salt concentration, and the salt type $\times$ concentration interaction were significant for both hypocotyl length and radicle length in GS, but only for hypocotyl length in IT. Salinity type and salinity concentration had significant effects on radicle length in IT, but their interactive effect was not significant (Table 1). Further analysis showed that the hypocotyl and radicle growth under salinity stress varied among cultivars, salinity types, and salinity concentrations (Table 3). 
Table 2. Effects of $\mathrm{NaCl}, \mathrm{Na}_{2} \mathrm{SO}_{4}, \mathrm{Na}_{2} \mathrm{CO}_{3}$, and $\mathrm{NaHCO}_{3}$ of various concentrations $(0,50$, $100,150,250$, and $300 \mathrm{mM}$ ) on growth of hypocotyl and radicle after seed germination in two sainfoin cultivars, "Gansu" (GS) and "Italian" (IT)

\begin{tabular}{|c|c|c|c|c|c|}
\hline \multicolumn{2}{|c|}{ Stress } & \multicolumn{2}{|c|}{ GS } & \multicolumn{2}{|c|}{ IT } \\
\hline Salinity type & $\begin{array}{c}\begin{array}{c}\text { Concentration } \\
(\mathbf{m M})\end{array} \\
\end{array}$ & $\begin{array}{c}\text { Hypocotyl length } \\
(\mathbf{m m})\end{array}$ & $\begin{array}{c}\text { Radicle length } \\
(\mathrm{mm})\end{array}$ & $\begin{array}{c}\text { Hypocotyl length } \\
(\mathbf{m m})\end{array}$ & $\begin{array}{c}\text { Radicle length } \\
(\mathbf{m m})\end{array}$ \\
\hline \multirow{7}{*}{$\mathrm{NaCl}$} & 0 & $26.33 \pm 6.46^{\mathrm{a}}$ & $82.56 \pm 10.67^{\mathrm{a}}$ & $24.00 \pm 5.61^{\mathrm{a}}$ & $74.78 \pm 15.72^{\mathrm{a}}$ \\
\hline & 50 & $14.22 \pm 7.64^{b}$ & $57.78 \pm 12.57^{b}$ & $14.78 \pm 3.59^{b}$ & $59.00 \pm 8.27^{\mathrm{b}}$ \\
\hline & 100 & $5.00 \pm 1.93^{\mathrm{c}}$ & $49.56 \pm 6.24^{c}$ & $7.33 \pm 3.87^{\mathrm{c}}$ & $41.67 \pm 8.07^{\mathrm{c}}$ \\
\hline & 150 & $5.00 \pm 3.16^{\mathrm{c}}$ & $41.00 \pm 7.22^{\mathrm{d}}$ & $7.33 \pm 4.24^{\mathrm{c}}$ & $37.22 \pm 8.75^{\mathrm{c}}$ \\
\hline & 200 & $3.33 \pm 0.50^{\mathrm{c}}$ & $25.67 \pm 3.70^{\mathrm{e}}$ & $3.78 \pm 1.39^{\mathrm{cd}}$ & $19.44 \pm 6.38^{\mathrm{d}}$ \\
\hline & 250 & $3.33 \pm 0.86^{\mathrm{c}}$ & $10.33 \pm 5.07^{\mathrm{f}}$ & $3.11 \pm 0.92^{\mathrm{d}}$ & $11.44 \pm 6.12^{\mathrm{de}}$ \\
\hline & 300 & $2.67 \pm 1.00^{\mathrm{c}}$ & $6.11 \pm 2.36^{\mathrm{f}}$ & $1.22 \pm 0.44^{\mathrm{d}}$ & $1.78 \pm 0.83^{\mathrm{e}}$ \\
\hline \multirow{7}{*}{$\mathrm{Na}_{2} \mathrm{SO}_{4}$} & 0 & $26.33 \pm 6.46^{\mathrm{a}}$ & $82.56 \pm 10.67^{\mathrm{a}}$ & $20.67 \pm 2.87^{\mathrm{a}}$ & $72.00 \pm 12.41^{\mathrm{a}}$ \\
\hline & 50 & $12.22 \pm 2.22^{b}$ & $45.78 \pm 10.45^{\mathrm{b}}$ & $8.00 \pm 4.47^{\mathrm{b}}$ & $47.17 \pm 7.80^{\mathrm{b}}$ \\
\hline & 100 & $7.11 \pm 3.01^{\mathrm{c}}$ & $39.89 \pm 7.18^{\mathrm{b}}$ & $4.00 \pm 1.41^{\mathrm{c}}$ & $35.17 \pm 7.78^{\mathrm{b}}$ \\
\hline & 150 & $3.44 \pm 0.88^{\mathrm{d}}$ & $26.11 \pm 3.75^{\mathrm{c}}$ & $2.83 \pm 0.75^{\mathrm{c}}$ & $25.5 \pm 7.71^{\mathrm{bc}}$ \\
\hline & 200 & $3.11 \pm 1.26^{\mathrm{d}}$ & $14.44 \pm 7.41^{\mathrm{d}}$ & $2.83 \pm 0.75^{\mathrm{c}}$ & $15.5 \pm 1.97^{\mathrm{cd}}$ \\
\hline & 250 & $2.11 \pm 0.60^{\mathrm{d}}$ & $9.56 \pm 3.84^{\mathrm{de}}$ & $2.75 \pm 1.25^{\mathrm{c}}$ & $5.75 \pm 1.89^{\mathrm{de}}$ \\
\hline & 300 & $1.33 \pm 0.50^{\mathrm{d}}$ & $4.00 \pm 1.22^{\mathrm{e}}$ & $1.00 \pm 0.00^{\mathrm{c}}$ & $2.00 \pm 1.15^{\mathrm{e}}$ \\
\hline \multirow{4}{*}{$\mathrm{Na}_{2} \mathrm{CO}_{3}$} & 0 & $24.00 \pm 1.87^{\mathrm{a}}$ & $74.89 \pm 5.22^{\mathrm{a}}$ & $24.00 \pm 1.87^{\mathrm{a}}$ & $74.89 \pm 7.29^{\mathrm{a}}$ \\
\hline & 50 & $10.88 \pm 2.31^{\mathrm{b}}$ & $11.00 \pm 1.82^{\mathrm{b}}$ & $10.44 \pm 0.95^{\mathrm{b}}$ & $10.22 \pm 3.59^{b}$ \\
\hline & 100 & $1.00 \pm 0.00^{\mathrm{c}}$ & $1.33 \pm 0.33^{\mathrm{c}}$ & - & - \\
\hline & 150 & - & - & - & - \\
\hline \multirow{5}{*}{$\mathrm{NaHCO}_{3}$} & 0 & $24.00 \pm 1.87^{\mathrm{a}}$ & $74.89 \pm 5.22^{\mathrm{a}}$ & $24.00 \pm 1.87^{\mathrm{a}}$ & $74.89 \pm 7.29^{\mathrm{a}}$ \\
\hline & 50 & $18.75 \pm 1.50^{\mathrm{ab}}$ & $18.13 \pm 2.02^{b}$ & $13.67 \pm 1.84^{b}$ & $11.67 \pm 2.72^{\mathrm{b}}$ \\
\hline & 100 & $15.71 \pm 1.14^{\mathrm{bc}}$ & $5.71 \pm 0.80^{\mathrm{c}}$ & $17.00 \pm 1.22^{b}$ & $4.33 \pm 1.08^{b}$ \\
\hline & 150 & $10.00 \pm 1.22^{\mathrm{c}}$ & $4.50 \pm 0.95^{\mathrm{c}}$ & $4.40 \pm 0.92^{\mathrm{c}}$ & $6.00 \pm 1.54^{\mathrm{b}}$ \\
\hline & 200 & - & - & - & - \\
\hline
\end{tabular}

Columns with different lowercase letters indicate significant differences at $\mathrm{P}<0.05$ (Duncan's test)

Table 3. A three-way ANOVA analysis of effects of salinity types, concentrations and cultivars on germination rates of seeds, and lengths of hypocotyls and radicles in sainfoin exposed to salinity stresses

\begin{tabular}{c|c|c|c|c|c|c|c}
\hline & $\mathbf{F v}$ & $\mathbf{F s}$ & $\mathbf{F c}$ & $\mathbf{F v} \times \mathbf{s}$ & $\mathbf{F v} \times \mathbf{c}$ & $\mathbf{F s} \times \mathbf{c}$ & $\mathbf{F v} \times \mathbf{s} \times \mathbf{c}$ \\
\hline df & 1 & 3 & 6 & 3 & 6 & 18 & 18 \\
Germination rate & $318.878^{* *}$ & $56.006^{* *}$ & $198.717^{* *}$ & $6.746^{* *}$ & $2.123^{*}$ & $6.956^{* *}$ & $1.791^{*}$ \\
Radicle length & 0.221 & $33.282^{* *}$ & $111.598^{* *}$ & $7.848^{* *}$ & $2.125^{*}$ & $8.340^{* *}$ & $2.187^{*}$ \\
Hypocotyl length & 0.355 & $8.523^{* *}$ & $76.845^{* *}$ & 2.326 & 2.002 & $1.984^{*}$ & 1.410 \\
\hline
\end{tabular}

$\mathrm{Fv}$, comparison of two sainfoin cultivars; Fs, comparison of two types of salinity; Fc, comparison of four concentrations of salinity; Fs $\times \mathrm{c}$, comparison of two kinds of salinity and four concentrations of salinity; $\mathrm{Fv} \times \mathrm{c}$, comparisons of two cultivars and four concentrations of salinity; $\mathrm{Fs} \times \mathrm{v} \times \mathrm{c}$, comparisons of two cultivars, two kinds of salinity, and four concentrations of salinity

$* P<0.05 ; * * P<0.01$

\section{Seed germination recovery in two sainfoin cultivars after different types of salts stresses}

To evaluate how harmful different types of salts and different salt concentrations were on seeds, the seeds ungerminated after seven days of salt treatment were transferred to distilled water, and germination recovery was tested. As shown in 
Figure 4, after $\mathrm{Na}_{2} \mathrm{SO}_{4}$ exposure, germination recovery increased with increasing salt concentration from 50 to $300 \mathrm{mM}$ in both cultivars, and the among of increase was significantly less in IT than in GS.
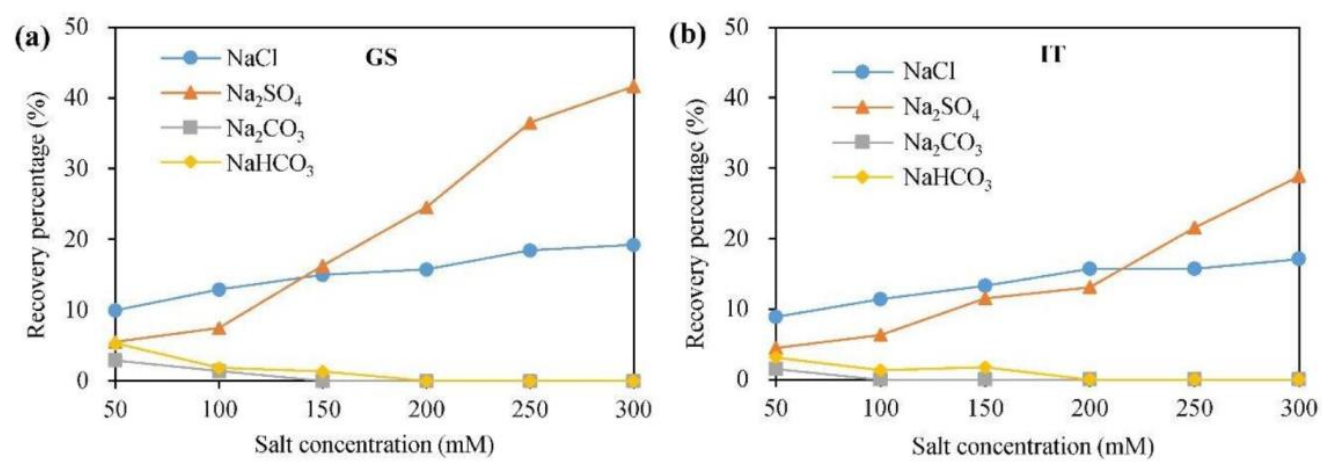

Figure 4. Recovery germination of seeds in two sainfoin cultivars "Gansu” (GS) (a) and "Italian" (IT) (b) subjected with $\mathrm{NaCl}, \mathrm{Na}_{2} \mathrm{SO}_{4}, \mathrm{Na}_{2} \mathrm{CO}_{3}$, and $\mathrm{NaHCO}_{3}$ of various concentrations $(50,100,150,200,250$, and $300 \mathrm{mM})$ for $7 \mathrm{~d}$

After $\mathrm{NaCl}$ stress, the recovery germination percentage (RGP) maintained the stable levels with increasing salt concentration in both GS and IT. Compared to the two neutral salts, after exposure to two alkaline salts, RGP significantly declined with increasing salt concentration. Although germination recovery also occurred in alkaline salt treatments, RGP was very low, and the maximum RGP was only 5\%. The RGP reached zero when the concentration of $\mathrm{Na}_{2} \mathrm{CO}_{3}$ was 100 and $150 \mathrm{mM}$ in IT and GS, respectively. However, recovery germination did not occur in either GS or IT when concentrations of $\mathrm{NaHCO}_{3}$ exceeded $200 \mathrm{mM}$ (Fig. 4a, b). These results suggest that alkaline salinities are more harmful to seeds of both sainfoin cultivars than neutral salinities.

Threshold and critical salt concentrations for the germination of seeds and growth of hypocotyl and radicle in two sainfoin cultivars under different types of salts stresses

As shown in Table 4, both threshold and critical salinity concentrations for seed germination were relatively higher under neutral salts than under alkaline salts for both cultivars. Under neutral salts, GS exhibited higher threshold concentrations of $200 \mathrm{mM}$ $\mathrm{NaCl}$ and $150 \mathrm{mM} \mathrm{Na} 2 \mathrm{SO}_{4}$ and higher critical concentrations of $250 \mathrm{mM} \mathrm{NaCl}$ and $200 \mathrm{mM} \mathrm{Na} \mathrm{SO}_{4}$, whereas IT showed relatively lower threshold and critical concentrations. Under alkaline salts, GS displayed the same threshold and critical concentrations as IT in both $\mathrm{Na}_{2} \mathrm{CO}_{3}$ and $\mathrm{NaHCO}_{3}$ conditions (Table 4).

\section{Discussion}

\section{The different effects of neutral and alkaline salinities on seed germination and recovery of two sainfoin cultivars}

Both neutral and alkaline salts inhibited seed germination, with germination significantly reduced with increasing salt concentrations (Figs. 1 and 2). For example, the germination rate of GS under $50 \mathrm{mM}$ of neutral salts was as high as the control 
$(0 \mathrm{mM})(>80 \%)$ (Fig. 1a, b), and the length of the radicle and hypocotyl exceeded 12 and $45 \mathrm{~mm}$, respectively (Table 2). However, few seeds germinated $(<30 \%)$ at a concentration of $300 \mathrm{mM}$ (Fig. la, b), and the lengths of the hypocotyl and radical at this high salt concentration were reduced by more than $90 \%$ (Table 2). In alkaline salinities, hypocotyl and radicle length were reduced to zero (Table 2). Similar results were also found in Haloxylon ammodendron (Huang et al., 2003), in which the germination rate gradually declined with increasing salinity concentrations.

Table 4. The threshold and critical salt concentration for the seed germination, and the hypocotyl and radicle growth in two sainfoin cultivars "Gansu" (GS) and "Italian" (IT) exposed to different salts stresses

\begin{tabular}{c|c|c|c|c|c|c|c}
\hline \multirow{2}{*}{ Cultivars } & \multirow{2}{*}{ Salinity } & \multicolumn{3}{|c|}{ Threshold salinity concentration (mM) } & \multicolumn{3}{c}{ Critical salinity concertation (mM) } \\
\cline { 3 - 8 } & & Germination & Hypocotyl & Radicle & Germination & Hypocotyl & Radicle \\
\hline \multirow{6}{*}{$\mathrm{GS}$} & $\mathrm{NaCl}$ & 200 & 50 & 50 & 250 & 100 & 150 \\
& $\mathrm{Na}_{2} \mathrm{SO}_{4}$ & 150 & 50 & 50 & 200 & 50 & 100 \\
& $\mathrm{Na}_{2} \mathrm{CO}_{3}$ & 50 & $50^{*}$ & $50^{*}$ & 50 & 50 & 50 \\
& $\mathrm{NaHCO}_{3}$ & 100 & 100 & $50^{*}$ & 100 & 100 & 50 \\
\hline \multirow{6}{*}{$\mathrm{IT}$} & $\mathrm{NaCl}$ & 150 & 50 & 50 & 250 & 100 & 150 \\
& $\mathrm{Na}_{2} \mathrm{SO}_{4}$ & 100 & 50 & 100 & 200 & 50 & 100 \\
& $\mathrm{Na}_{2} \mathrm{CO}_{3}$ & 50 & 50 & $50^{*}$ & 50 & 50 & $50^{*}$ \\
& $\mathrm{NaHCO}_{3}$ & 100 & 50 & $50^{*}$ & 100 & 150 & 50 \\
\hline
\end{tabular}

Threshold salinity concentration is defined as the highest level of salinity resulting in non-significant decrease, and the critical salinity concertation is defined as the level of salinity resulting in a $50 \%$ decrease of seed germination or lengths of hypocotyls and radicles. "*" represents significant decrease compared to the control from $50 \mathrm{mM}$ salinity concentration

It is well-known that neutral salts and alkaline salts impose distinct types of stresses (Shi and Sheng, 2005). Plants exposed to alkaline conditions experienced not only ionic stress but also high $\mathrm{pH}$ stress, which aggravates the effects of ionic toxicity and osmotic stress on seeds and damages the seed embryo (Yang et al., 2009). In the present study, the differences between neutral and alkaline salinities were further investigated. It is clear that alkaline salinity was more harmful than neural salinity to sainfoin seed germination and seedling growth (Table 2). Both GS and IT cultivars had higher germination under neutral salinities $\left(\mathrm{NaCl}\right.$ and $\left.\mathrm{Na}_{2} \mathrm{SO}_{4}\right)$ than under alkaline salinities $\left(\mathrm{NaHCO}_{3}\right.$ and $\left.\mathrm{Na}_{2} \mathrm{CO}_{3}\right)$. Under $\mathrm{Na}_{2} \mathrm{CO}_{3}$, seeds germinated only at a concentration of $50 \mathrm{mM}$. Similarly, under $\mathrm{NaHCO}_{3}$ stress, germination did not occur at concentrations exceeding $150 \mathrm{mM}$. However, at even $300 \mathrm{mM}$ concentrations of $\mathrm{NaCl}$ and $\mathrm{Na}_{2} \mathrm{SO}_{4}$ seeds still germinated (Figs. 1 and 2). Additionally, sainfoin exhibited a relatively higher threshold concentration of neutral salts than alkaline salts during germination. The threshold concentrations of $\mathrm{NaCl}$ and $\mathrm{Na}_{2} \mathrm{SO}_{4}$ for $\mathrm{GS}$ germination were 200 and $150 \mathrm{mM}$, while the corresponding thresholds of alkaline salts $\left(\mathrm{Na}_{2} \mathrm{CO}_{3}\right.$ and $\left.\mathrm{NaHCO}_{3}\right)$ were 50 and $100 \mathrm{mM}$, respectively. However, for germination of the IT cultivar, the critical concentrations of $\mathrm{NaCl}$ and $\mathrm{Na}_{2} \mathrm{SO}_{4}$ were 250 and $200 \mathrm{mM}$, while the corresponding critical concentrations of alkaline salts $\left(\mathrm{Na}_{2} \mathrm{CO}_{3}\right.$ and $\left.\mathrm{NaHCO}_{3}\right)$ were 50 and $100 \mathrm{mM}$, respectively (Table 4). These results suggest that damage caused by alkaline salts is more serious than those caused by neutral salts. In previous studies, it was observed that the damage due to alkaline salts are often more complex, and the 
process and degree of damage, as well as the breakdown of ecological performance, are more severe than those due to neutral salts (Yang et al., 2009).

In the neutral salt treatments, the recovery germination percentage increased with increasing salt concentration (Fig. 4). For instance, the recovery percentages in GS increased from $5 \%$ to $40 \%$ under $\mathrm{Na}_{2} \mathrm{SO}_{4}$, with the maximum recovery germination percentage occurring after exposure to $300 \mathrm{mM}$, indicating that neutral salts only temporarily inhibited seed germination in sainfoin. However, under alkaline salt stress, the recovery germination percentage sharply decreased with increasing salt concentrations. In addition, both cultivars exhibited lower recovery germination percentage in alkaline conditions compared to neutral salinity conditions (Fig. 4). These results implied that alkaline salinity not only temporarily inhibited seed germination but also led to prolonged toxicity.

\section{The different tolerance to salt stresses in two sainfoin cultivars}

Both neutral and alkaline salinity stresses led to reduced germination rate with increasing salt concentration. The reduction in germination was proportional to the concentration of $\mathrm{Na}^{+}$, with more $\mathrm{Na}^{+}$leading to lower rates of germination ( $\mathrm{Hu}$ et al., 2018). Under neutral salt conditions, the germination curve of $250 \mathrm{mM}$ in $\mathrm{NaCl}$ almost coincided with that of $\mathrm{Na}_{2} \mathrm{SO}_{4}$ at $200 \mathrm{mM}$ in both GS and IT. Similarly, under alkaline conditions, the germination curve of $50 \mathrm{mM}$ in $\mathrm{Na}_{2} \mathrm{CO}_{3}$ was almost the same as that of $\mathrm{NaHCO}_{3}$ at $100 \mathrm{mM}$ (Figs. $1 a, b$ and $2 a, b$ ). These results demonstrated that $\mathrm{Na}^{+}$might be toxic to seed germination. $\mathrm{Na}^{+}$has been reported to have a physiological role in seedlings of sugar beet (Wu et al., 2015b), and high absorption of $\mathrm{Na}^{+}$inhibited and decreased germination rate (Carpýcý et al., 2009). Toxicity of $\mathrm{Na}^{+}$may therefore be the main cause of reduced germination with increasing salinity concentration.

Salt tolerance has been shown to differ during seed germination and vary among different plant varieties (Hu et al., 2018). Although GS and IT exhibited a very similar appearance and displayed the same patterns of response to saline and alkaline stresses, there were nonetheless obvious differences in salt tolerance between the two cultivars. GS was more tolerant to neutral salt stress during germination, as the germination rate showed a relatively higher threshold concentration compared to IT (Table 4). Additionally, the radicles and hypocotyls of seedlings grown under $\mathrm{NaCl}$ and $\mathrm{Na}_{2} \mathrm{SO}_{4}$ were also longer in GS than in IT. These results confirmed that GS was more tolerant to $\mathrm{NaCl}$ and $\mathrm{Na}_{2} \mathrm{SO}_{4}$. However, both GS and IT experienced sharp reductions in germination at higher concentrations of alkaline salts (Fig. 3), which was exemplified by the lower critical concentration at $50 \mathrm{mM} \mathrm{Na}_{2} \mathrm{CO}_{3}$ and at $100 \mathrm{mM} \mathrm{NaHCO} 3$ (Table 4). These results implied that sainfoin is extremely sensitive to alkaline conditions.

It is well documented that the role of the seed coat is to protect the embryo from harmful environmental conditions (Wierzbicka and Obidzińska, 1998; Yang et al., 2012). The effect of abiotic stress on seed germination of different crop cultivars depends upon different seed structures (Wierzbicka and Obidzińska, 1998; Ashraf and Foolad, 2005). In general, a solid seed coat can protect the seed embryo from salt toxicity, particularly because of its wide variability in structure compared to other tissues or organs (Wierzbicka and Obidzińska, 1998). The seed coat, therefore, is the major barrier to salinity stress, and it prevents embryo toxicity prior to seed coat degradation by the germinating embryonic roots (Hu et al., 2018). As the two sainfoin cultivars have similar structures of seeds, the reason for the stronger salinity tolerance 
of GS compared to that of IT may be attributed to its higher quality seeds (i.e. the heavier mass of 100 seeds), which can hold more dry matter and more energy in the seed embryo.

\section{Conclusions}

Different types of salts inhibited seed germination and growth of hypocotyls and radicles, with increasing inhibition with increasing salt concentrations. Salts affected sainfoin germination and early growth in the following order: $\mathrm{Na}_{2} \mathrm{CO}_{3}>\mathrm{NaHCO}_{3}>\mathrm{Na}_{2} \mathrm{SO}_{4}>\mathrm{NaCl}$. Neutral salinity only temporarily inhibited germination, whereas alkaline salinity temporarily inhibited germination during exposure but also proved toxic to sainfoin seeds even after removal of the salts. Thus, the effects of neutral salinity and alkaline salinity were different, and damage due to alkaline salinity was more severe than that of neutral salinity. GS seeds germinated and grew more rapidly compared to IT seeds under saline-alkaline stress, suggesting that GS is more salt-tolerant. However, the molecular mechanisms underling the response of sainfoin to saline-alkaline stress need to be addressed in the future research.

Acknowledgements. This research was funded by the National Natural Science Foundation of China, grant number 31860404; Science and Technology Department of Gansu Province, grant number 21YF5FA082; Lanzhou Science and Technology Bureau, grant number 2017-4-94. We would like to thank all the people involved in this project and the reviewers who provided constructive comments. We would also like to thank Dr. Adam Roddy at Yale University for his assistance with English language and grammatical editing.

\section{REFERENCES}

[1] Abbasdokht, H.; Gholami, A.; Asghari, H. (2014): Halopriming and hydropriming treatments to overcome salt and drought stress at germination stage of corn (Zea mays L.). - Desert 19: 27-34.

[2] Ahmadvand, G.; Soleimani, F.; Saadatian, B.; Pouya, M. (2012): Effects of seed priming on germination and emergence traits of two soybean cultivars under salinity stress. International Journal of Applied and Basic Sciences 3: 234-241.

[3] Albuquerque, F. E.; Carvalho, N. M. (2003): Effect of the type of environmental stress on the emergence of sunflower (Helianthus annus L.), soybean (Glycine max (L.) Merril) and maize (Zea mays L.) seeds with different levels of vigor. - Seed Science \& Technology 31: 465-479.

[4] Ashraf, M.; Foolad, M. R. (2005): Pre-sowing seed treatment - A shotgun approach to improve germination, plant growth, and crop yield under saline and non-saline conditions. - Advances in Agronomy 88: 223-271.

[5] Baldinger, L.; Hagmüller, W.; Minihuber, U.; Matzner, M.; Zollitsch, W. (2014): Sainfoin seeds in organic diets for weaned piglets-utilizing the protein-rich grains of a long-known forage legume. - Renewable Agriculture and Food Systems 31: 12-21.

[6] Carpýcý, E. B.; Celýk, N.; Bayram, G. (2009): Effects of salt stress on germination of some maize (Zea mays L.) cultivars. - African Journal of Biotechnology 8: 4918-4922.

[7] Cirujeda, A.; Marí, A. I.; Murillo, S.; Aibar, J.; Pardo, G.; Solé-Senan, X. O. (2019): May the inclusion of a legume crop change weed composition in cereal fields? Example of sainfoin in Aragon (Spain). - Agronomy 9: 134. 
[8] Gebremedhn, Y.; Berhanu, A. (2013): The role of seed priming in improving seed germination and seedling growth of maize (Zea mays L.) under salt stress at laboratory conditions. - African Journal of Biotechnology 12: 6484-6490.

[9] Gorai, M.; Neffati, M. (2007): Germination responses of Reaumuria vermiculata to salinity and temperature. - Annals of Applied Biology 151: 53-59.

[10] Hu, H.; Liu, H.; Liu, F. (2018): Seed germination of hemp (Cannabis sativa L.) cultivars responds differently to the stress of salt type and concentration. - Industrial Crops and Products 123: 254-261.

[11] Huang, Z.; Zhang, X.; Zheng, G.; Gutterman, Y. (2003): Influence of light, temperature, salinity and storage on seed germination of Haloxylon ammodendron. - Journal of Arid Environments 55: 453-464.

[12] Idris, Y. A.; Ali, S. A. M. (2015): Response of maize (Zea mays L.) to sodium chloride stress at early growth stages. - International Journal of Agronomy and Agricultural Research 6: 68-74.

[13] Khalil, C.; Houssein, B. E.; Hassan, B.; Fouad, M. (2016): Comparative salt tolerance study of some acacia species at seed germination stage. - Asian Journal of Plant Sciences 15: 66-74.

[14] Li, X.; Zhao, W. Z. (2018): Effects of salt-alkaline mixed stresses on seed germination and seeding growth of Bassia dasyphylla in desert region. - Journal of Desert Research 38: 300-306.

[15] Lu, S. W.; Li, T. L.; Jiang, J. (2010): Effects of tomato fruit under $\mathrm{Na}^{+}$-salt and $\mathrm{Cl}^{-}-\mathrm{salt}^{-}$ stresses on sucrose metabolism. - African Journal of Agricultural Research 5: 2227-2231.

[16] Mohajer, S.; Taha, R. M.; Lay, M. M.; Esmaeili, A. K.; Khalili, M. (2014): Stimulatory effects of gamma irradiation on phytochemical properties, mitotic behaviour, and nutritional composition of sainfoin (Onobrychis viciifolia Scop.). - The Scientific World Journal 2014: 1-9.

[17] Munns, R.; Tester, M. (2008): Mechanisms of salinity tolerance. - Annual Review of Plant Biology 59: 651-81.

[18] Muscolo, A.; Sidari, M.; Anastasi, U.; Santonoceto, U.; Maggio, A. (2014): Effect of PEG-induced drought stress on seed germination of four lentil genotypes. - Journal of Plant Interactions 9(1): 354-363.

[19] Niu, Y.; Yang, X. Y.; Dai, C. F.; Wang, B. W.; Ren, G. L.; Wu, J. L.; Wang, F. B.; Chen, X. H. (2018): Related indices selection of soybean salt tolerance at germination and seedling stages. - Soybean Science 37: 216-223.

[20] Okcu, M.; Topaloglu, F. N. (2019): Effect of different gibberellic acid doses treatment on seed germination of wild sainfoin (Onobrychis vichfolia). - Fresenius Environmental Bulletin 28: 1062-1068.

[21] Partheeban, C.; Chandrasekhar, C. N.; Jeyakumar, P.; Ravikesavan, R.; Gnanam, R. (2017): Effect of PEG induced drought stress on seed germination and seedling characters of maize (Zea mays L.) genotypes. - International Journal of Current Microbiology and Applied Sciences 6: 1095-1104.

[22] Petrovic, G.; Jovicic, D.; Nikolic, Z.; Tamindzic, G.; Ignjatov, M.; Milosevic, D.; Milosevic, B. (2016): Comparative study of drought and salt stress effects on germination and seedling growth of pea. - Genetika 48: 373-381.

[23] Radic, V.; Balalic, I.; Jacimovic, G.; Nastasic, A.; Savic, J.; Marjanovic-Jeromela, A. (2019): Impact of drought and salt stress on seed germination and seedling growth of maize hybrids. - Genetika 51: 743-756.

[24] Shi, D.; Sheng, Y. (2005): Effect of various salt-alkaline mixed stress conditions on sunflower seedlings and analysis of their stress factors. - Environmental and Experimental Botany 54: 8-21.

[25] Wierzbicka, M.; Obidzińska, J. (1998): The effect of lead on seed imbibition and germination in different plant species. - Plant Science 137: 155-171. 
[26] Wu, G. Q.; Shui, Q. Z.; Wang, C. M.; Zhang, J. L.; Yuan, H. J.; Li, S. J.; Liu, Z. J. (2015a): Characteristics of $\mathrm{Na}^{+}$uptake in sugar beet (Beta vulgaris L.) seedlings under mild salt conditions. - Acta Physiologiae Plantarum 37: 1-13.

[27] Wu, H.; Shabala, L.; Liu, X.; Azzarello, E.; Zhou, M.; Pandolfi, C.; Pandolfi, C.; Chen, Z.; Bose, J.; Mancuso, S.; Shabala, S. (2015b): Linking salinity stress tolerance with tissue-specific $\mathrm{Na}^{+}$sequestration in wheat roots. - Frontiers in Plant Science 6: 71.

[28] Wu, G. Q.; Jia, Z.; Liu, H. L.; Wang, C. M.; Li, S. J. (2017): Effect of salt stress on growth, ion accumulation, and distribution in sainfoins (Onobrychis viciaefolia) seedlings. - Pratacultural Science 34: 1661-1668.

[29] Wu, G. Q.; Li, H., Zhu, Y. H., Li, S. J. (2021): Comparative physiological response of sainfoin (Onobrychis viciaefolia) seedlings to alkaline and saline-alkaline stress. Journal of Animal and Plant Sciences. 31(4): 1028-1035.

[30] Yang, C. W.; Zhang, M. L.; Liu, J.; Shi, D. C.; Wang, D. L. (2009): Effects of buffer capacity on growth, photosynthesis, and solute accumulation of a glycophyte (wheat) and a halophyte (Chloris virgata). - Photosynthetica 47: 55-60.

[31] Yang, X.; Baskin, J. M.; Baskin, C. C.; Huang, Z. (2012): More than just a coating: ecological importance, taxonomic occurrence and phylogenetic relationships of seed coat mucilage. - Perspectives in Plant Ecology Evolution \& Systematics 14: 434-442.

[32] Zahra, K.; Ifar, M.; Motamedi, M. (2011): Effects of NaCl salinity on maize (Zea mays L.) at germination and early seedling stage. - African Journal of Biotechnology 11: 298304.

[33] Zhang, H.; Zhang, G.; Lu, X.; Zhou, D.; Han, X. (2014): Salt tolerance during seed germination and early seedling stages of 12 halophytes. - Plant and Soil 388: 229-241. 